\title{
Üst Ekstremite Yanıklarında Erken Dönemde Fonksiyonu Etkileyen Faktörlerin Araştırılması
}

Investigation of Factors Affecting the Function at Early Period in Upper Extremity Burns

\author{
Özden ÖZKAL ${ }^{1}$, Semra TOPUZ ${ }^{2}$ \\ 1 Dr. Öğr. Üyesi, Bursa Uludağ Üniversitesi, Sağlık bilimleri Fakültesi, Fizyoterapi ve Rehabilitasyon Bölümü, Bursa, Türkiye. \\ ${ }^{2}$ Doç. Dr., Hacettepe Üniversitesi, Fizik Tedavi ve Rehabilitasyon Fakültesi, Ankara, Türkiye.
}

\section{ÖZ}

\begin{abstract}
Amaç: Üst ekstremite yanık yaralanması olan bireylerde erken dönemde üst ekstremite ile ilişkili özür etkileyen parametreleri araştırmaktı. Gereç ve Yöntem: Çalışmaya unilateral ve bilateral üst ekstremite yanık yaralanması olan 34 ( $26 \mathrm{~K} ; 8 \mathrm{E}$ ) birey dahil edildi. Bireylerin üst ekstremite ile ilişkili özür düzeyi için hızl-kol-omuz-el sorunları anketi (Q-DASH), kavrama kuvveti için Jamar el dinamometresi , kinezyofobi düzeyi için Tampa Kinezyofobi Ölçeği ve ağrı düzeyi için Görsel Analog Skalası kullanıldı. Sonuçlar: Çoklu doğrusal regresyon analiz sonuçlarına göre, eklemde yanık varlığı ve ağıı düzeyinin, üst ekstremite fonksiyonunun anlamlı belirleyicileri olduğu saptandı $(p<0,05)$. Ayrıca, eklemi içeren yanık yaralanması olan bireylerde Q-DASH skoru, kinezyofobi ve ağrı düzeyi daha yüksek bulunurken, kavrama kuvvetinin daha düşük olduğu bulundu $(p<0,05)$. Üst ekstremite ile ilişkili zozür düzeyi, kinezyofobi, kavrama kuvveti ve ağı parametreleri açısından bilateral ve unilateral yanık yaralanması olan bireyler arasında fark bulunmadı $(p>0,05)$. Tartışma: Yanık yaralanmasının özellikle eldeki bir eklemde bulunması ve artmış ağrı düzeyinin erken dönemde özür düzeyini olumsuz etkilediği gösterildi. Eklemde yanık yaralanması olan bireylerin üst ekstremite ile ilişkili özür düzeyine ek olarak, ağrı şiddetinin, kinezyofobi düzeyinin ve kavrama kuvvetinin de negatif etkilendiği belirlendi.
\end{abstract}

Anahtar kelimeler: Yanıklar; Üst ekstremite; Ağrı; El yaralanmaları

\section{ABSTRACT}

Purpose: To investigate the parameters affecting upper limb function in the early period in subjects with upper limb burn injury. Material and Methods: This study included a total of 34 (26 F; 8 M) individuals with upper limb burn injury. Disabilities of the Arm Shoulder and Hand Questionnaire (QuickDASH) for upper extremity functions of subjects, Jamar hand dynamometer for grip strength, Tampa Kinesiophobia Scale for kinesiophobia level and Visual Analogue Scale for pain level were used. Results: QuickDASH score, kinesiophobia and pain levels were higher while grip strength was lower in individuals with joint involvement of burn injury $(p<0,05)$. There was no difference between individuals with bilateral and unilateral burn injuries in terms of upper limb function, kinesiophobia, grip strength, and pain parameters $(p>0,05)$. According to the multiple regression analysis results, the presence of joint involvement of burn injury and pain levels were determined as significant predictors of upper extremity function $(p<0,05)$. Discussion: It was shown that the presence of a burn injury in a joint in the hand and increased pain level adversely affects upper extremity functions in the early period. In addition to the upper limb functions of individuals with burn injuries in the joint, pain severity, kinesiophobia and grip strength were also negatively affected.

Keywords: Burns; Upper extremity; Pain; Hand injuries 
Yanık yaralanması, doku hasarı ile birlikte fiziksel ve psikolojik etkileri olan bir travmadır (Ghezeljeh, Ardebili ve Rafii, 2017). El, tüm yanık yaralanmalarında \% 80 oranında yanıktan en çok etkilenen vücut bölümlerinden biridir (Luce, 2000). Amerikan Yanık Derneği'nin sınıflandırmasına göre toplam yanık yüzey alanı (TYYA) ve derinliği gözetilmeksizin eli içine alan yanıklar majör yanık yaralanması kapsamında değerlendirilmektedir (Edlich, Larkham, O'Hanlan ve ark.,1978). EI yanıkları mortaliteye sebep olmamasına rağmen, duyu, kas kuvveti, eklem hareket açıklığı ve ince motor becerilerde kayıplara yol açabilir (Schneider, Holavanahalli, Helm ve ark., 2008). Yanık yaralanmasını takiben görülen bu komplikasyonlar giyinme ve yemek gibi günlük yaşam aktivitelerinin gerçekleştirmesinin yanı sıra yazı yazma, mesleki faaliyetler gibi ince motor becerileri ve yaşam kalitesini olumsuz yönde etkileyebilir (Omar, Hegazy, ve Mokashi, 2012).

Literatürde üst ekstremite yanık yaralanmalarını takiben erken ve geç dönemde fonksiyon ve kas kuvvetini değerlendiren çalışmalar mevcuttur (Jarrett, McMahon ve Stiller, 2008; Schneider, Qu, Lowry ve ark., 2012; Wu, Edgar ve Wood 2007; Mazzetto-Betti, Amâncio, Farina ve ark., 2009). Yanık yaralanması olan bireylerin uzun süreli takibinin yapıldığı bir çalışmada (Jarrett, 2008) üst ekstremite ile ilişkili özür düzeyini hızı kol-omuz-el sorunları anketi (QDASH) ile değerlendirilmiş ve Q-DASH anketi puanının TYYA ile ilişkili olduğu belirtilirken, yanık yüzey alanının etkisi gözetilmeksizin tüm bireylerin fonksiyonlarının taburculukta başlangıca göre daha kötü olduğu ancak 6 ay içerisinde fonksiyonların norm değerlere yaklaştığı bildirilmiştir. Mazzetto-Betti ve arkadaşlarının (Mazzetto-Betti, 2009) yüksek voltaj elektrik yanıklarında yaralanmayı takiben bir yıl içerisinde bireylerin üst ekstremite fonksiyonel durumlarını kol-omuz-el sorunları anketi ile değerlendirmişler ve bireylerin kavrama kuvveti ile üst ekstremite fonksiyonlarında azalma olduğunu göstermişlerdir.

Literatürde üst ekstremite yanıklarında fonksiyonel iyileşmenin değerlendirildiği çalışmalara ek olarak, iyileşme sürecini etkileyen faktörlerin araştırıldığı sınırlı sayıda çalışma mevcuttur (Vang, Sun, Wu ve ark., 2015; Arifi, Duci, Zatriqi ve ark., 2014) . Vang ve arkadaşlarının (Vang ve ark.,2015) retrospektik olarak yürüttükleri çalışmada, yanık derinliği, TYYA ve yaralanma öncesi genel sağlık durumunun el yanıklarında cerrahi sayısı ve amputasyon, kontraktür gibi kronik dönem komplikasyonları etkileyen faktörler olduğunu bildirmişlerdir. Retrospektif olarak 572 el yanığı olan bireyin takip edildiği bir başka çalışmada ise kronik dönemde ortaya çıkan kontraktürlerin yaralanmanın şiddeti ile ilişkili olduğunu belirtilmiştir (Arifi ve ark., 2014). Knigh ve arkadaşlarının yürüttüğü çalışmada (Knigh, Wasiak, Salway ve ark., 2017) unilateral veya bilateral el yanığı olan bireylerin yaralanma sonrası 2 . yılda, Michigan el sonuç anketi ile aktivite ve katılım kısıtılıklarını değerlendirmişler ve bunu etkileyen faktörleri araştırmışlardır. Sonuç olarak TYYA, yanık derinliği, geçirilmiş cerrahi varlığı ve hastanede yatış süresinin bağımsız ve anlamlı belirleyiciler olduğu gösterilmiştir. Mevcut çalışmalar üst ekstremitede fonksiyonel iyileşme ile yanığa özgü parametreler arasındaki ilişki odaklıdır. Akut dönemde üst ve alt ekstremitedeki yanık yaralanmaları ile ilgili olarak yapılmış çalışmaları incelediğimizde, yanığa özgü parametrelere ek olarak ağrı ve buna bağlı oluşan kinezyofobinin de bireylerde yaşam kalitesini azalttığı, iyileşme sürecini geciktirdiği ve fonksiyonel durumlarını olumsuz yönde etkilediği gösterilmiştir (Sgroi, Willebrand, Ekselius ve ark., 2005; Özkal, Topuz, Konan ve ark., 2017).

Üst ekstremite yanık yaralanmasını takiben akut dönemde özür düzeyinin olumsuz etkilendiği bilinmesine rağmen (Jarrett, 2008), yanığın eklemi içermesi, unilateral/bilateral yanık varlığı gibi detaylı yanık lokalizasyonun ile birlikte ağrı ve kinezyofobi gibi akut dönem komplikasyonların bu durumu ne yönde etkilediği bilinmemektedir. Ek olarak, yanık lokalizasyonun (bilateral/unilateral yanıklar ve eklemde yanık varlığı) üst ekstremite ile ilişkili özür düzeyi ile birlikte kavrama kuvveti, ağrı ve kinezyofobiye olan etkisi de araştırılmamıştır.

Çalışmanın birincil amacı üst ekstremite yanık yaralanması olan bireylerde, akut dönemde bireylerin üst ekstremite ile ilişkili özür düzeyi ile yanığa özgü özellikler (yanık tipi, yanık deriniliği, yanık lokalizasyonu, unilateral/bilateral yanık varlığı, yanığın eklemi içermesi), demografik özellikler (yaş, boy, vücut ağırlığı, cinsiyet) ve klinik ölçümler (kavrama kuvveti, ağrı ve kinezyofobi düzeyi ) arasındaki ilişkiyi araştırarak özür düzeyinin bağımsız belirleyicilerini ortaya koymaktır. İkincil amacı ise, yanık lokalizasyonun (unilateral-bilateral) ve (eklemi içereniçermeyen) üst ekstremite ile ilişkili özür düzeyi, kavrama kuvveti, ağrı ve kinezyofobi üzerine etkisini ortaya koymaktır. 


\section{GEREÇ VE YÖNTEM}

Katılımcılar

Çalışmaya Hacettepe Üniversitesi Hastanesi Yanık Ünitesi'ne başvuran unilateral veya bilateral üst ekstremite yanık yaralanması olan 34 birey dahil edildi. Çalışmaya katılmayı kabul eden bireylere çalışma kapsamında yapılacak değerlendirmeler ile ilgili bilgi verilerek yazılı onamları alındı. Çalışma için gerekli izin Hacettepe Üniversitesi Girişimsel Olmayan Etik Kurulu'ndan GO 19/1146 karar numarası ile alındı. Çalışmaya 18-50 yaş aralığında bulunan, üst ekstremitesinde yanık yaralanması olan, ayaktan pansumanla takip edilen ve yaralanmayı takiben en geç 1 hafta içerisinde kliniğine başvuran bireyler dahil edildi. Üst ekstremitenin haricinde farklı bir bölgede yanık yaralanması olan, el veya üst ekstremiteden (dirsek, omuz) geçirilmiş yanık yaralanması dışında yaralanma/ cerrahi hikayesi bulunan bulunan ve üst ekstremite fonksiyonunu etkileyebilecek tanı almış sistemik bir hastalığı olan (nörolojik hastalıklar, RA, diyabet..vb) bireyler çalışmaya dahil edilmedi. Katılımcıların demografik özellikleri ve yanık yaralanmasına ait bilgileri kaydedildi. Bireylerin üst ekstremite ile ilişkili özür düzeyi 11 soruluk hızlı kol-omuz-el sorunları anketi (Q-DASH), kavrama kuvveti el dinamometresi, ağrı şiddeti Görsel Analog Skalası, hareket etme korkuları Tampa Kinezyofobi Ölçeği kullanılarak değerlendirildi. Tüm değerlendirmeler yanık yaralanmasını takiben ilk 7 gün içerisinde yapıldı.

\section{Veri Toplama Araçları}

Demografik ve yanığa özgü değerlendirmeler: Bireylerin yaş, cinsiyet, boy, vücut ağırlığı, vücutkütle indeksi (VKI) demografik özellikler olarak kaydedildi. Yanığın oluşma şekli, yanık derinliği, yanık lokalizasyonu, eklemde yanık varlığı, unilateral/bilateral yanık varlığı ve TYYA(dokuzlar kuralına göre) kaydedildi. Dokuzlar kuralı (Johnson ve Richard, 2003) genellikle erişkinlerde kullanılan, vücut yüzey alanını \% 9'luk veya \% 9'luklardan oluşan \% 18'lik alanlara bölerek toplam yanık yüzey alanı hakkında bilgi veren hesaplama yöntemidir. Yöntemde, \% 9'luk alanların toplanmasından sonra geriye kalan \% 1' lik alan genital ve perineryum bölgesine aittir.

Üst ekstremite ile ilişkili özür düzeyi değerlendirilmesi: Bireylerin üst ekstremite ile ilişkili özür düzeyi değerlendirmesi için 11 soruluk Q-DASH anketi kullanıldı. Q-DASH anketi tüm üst ekstremite bozukluklarında, aktivite ve katılım kısıtıııklarını ölçen bir değerlendirme anketidir. Ankette 11 soruyla hastaların günlük yaşam aktiviteleri sırasındaki zorlanmaları sorgulanır. Likert skalası ile her cevap 1 ile 5 arasında iyiden kötüye doğru puanlandırılır. Q-DASH anketi puanının hesaplanabilmesi için 11 başlıktan en az 10'u yanıtlanmış olmalıdır. Q-DASH anketi puanı [( $\mathrm{n}$ toplam puanı)-1)/n]x25 (n cevaplanmış soru sayısına eşittir) formülüne göre hesaplandı. Anketin toplam puanı 0100 arasında değişkenlik göstermektedir. Yüksek puan üst ekstremite özür düzeyindeki kötüleşmeyi ifade eder. Türkçe geçerlik ve güvenirliği Düger ve arkadaşları (Düger, Yakut, Öksüz ve ark., 2006) tarafından yapılmıştır.

Kavrama kuvvetinin değerlendirilmesi: Katılımcıların kavrama kuvveti Jamar el dinamometresi ile değerlendirildi. Kavrama kuvveti oturur pozisyonda omuz nötralde, dirsek 90 o fleksiyonda el bileği nötralde olacak şekilde ölçüldü. Ölçüm her iki el için 3 kez tekrarlandı ve ortalaması kaydedildi (Bellace, Healy, Besser ve ark., 2000). Unilateral üst ekstremite yanıklarında kavrama kuvveti ölçüm sonuçları yanık taraf ve sağlam taraf olarak kaydedilirken, bilateral üst ekstremite yanıklarında ise kavrama kuvveti ölçüm sonuçları TYYA'ı daha fazla olan taraf yanık taraf, TYYA'ı az olan taraf daha az yanık taraf olarak kaydedildi.

Ağrı şiddetinin değerlendirilmesi: Bireylerin ağrıları görsel analog skalasına göre değerlendirildi. Bu skalada "0" hiç ağrım yok "10" dayanılmaz ağrı olarak ifade edilmektedir. Katılımcıların 10 cm'lik düz bir çizgi üzerinde hissettiği ağrıyı işaretlemeleri istendi ve bulunan değer $\mathrm{cm}$ cinsinden kaydedildi (Bijur, Silver ve Gallagher, 2001).

Kinezyofobinin değerlendirilmesi: Bireylerin ağrıya bağlı oluşan korku-kaçınma ve tekrar yaralanma korkuları 17 sorudan oluşan Tampa Kinezyofobi Ölçeği ile değerlendirildi. Ölçekte 4'lü Likert puanlaması (1=Kesinlikle katılmıyorum, 4=Tamamen katılıyorum) kullanılmaktadır. Ölçeğin puanlaması 17-68 arasında değişkenlik göstermektedir. Ölçekte kişinin aldığı puanın yüksek oluşu kinezyofobisinin yüksek olduğunu göstermektedir. Türkçe geçerlik ve güvenirliği Yılmaz ve arkadaşları (Yılmaz, Yakut, Uygur ve ark., 2011) tarafından yapılmıştır.

\section{Istatistiksel Analiz}

Veriler IBM İstatistik paket programı versiyon 21 kullanılarak analiz edildi. Tanımlayıcı analizler, ortalama (Ort) \pm standart sapma (SS) veya yüzde olarak ifade edildi. Verilerin normal dağılımlarını test etmek için histogram ve Kolmogorov-Smirnov/ShapiroWilk testleri kullanıldı. Q-DASH anketi puanını etkileyen 
istatistiksel olarak anlamlı ve bağımsız değişkenleri belirlemek için çok değişkenli doğrusal regresyon modeli kullanıldı. Analiz öncesi modele dahil edilecek sayısal veya kategorik değişkenler belirlendi. Bunun için öncelikle, Q-DASH anketi puanı ile sayısal değişkenler (yaş, boy, vücut ağırlığı, VKI, TYYA, kavrama kuvveti, kinezyofobi düzeyi ve ağrı düzeyi) arasındaki ilişki incelenirken Pearson veya Spearman korelasyon analizi kullanıldı. Q-DASH anketi puanının kategorik değişkenlere göre farklılık gösterip göstermediği, eğer değişken ikili ise (cinsiyet, yanık derinliği, eklemde yanık varlığı, bilateral/unilateral yanık varlığı) Mann-Whitney $U$ testi, ikiden fazla kategori içeriyorsa (yanık oluşma şekli, yanık lokalizasyonu) Kruskal-Wallis testi kullanılarak tespit edildi. Korelasyon ve karşılaştırmalı analiz testi sonuçlarına göre, QDASH anketi puanı ile anlamlı bir ilişki gösterdiği belirlenen sayısal veya kategorik değişkenler, çok değişkenli doğrusal regresyon modeline dahil edildi.

Eklemde yanığı olan ve olmayan ile bilateral ve unilateral yanık yaralanması olan bireylerin klinik değerlendirmelerinin gruplar arası karşılaştırmalarında verilerin normal dağılıma uymaması sebebiyle Mann-Whitney $U$ testi kullanıldı. İstatistiksel olarak anlamlılık düzeyi $p<0,05$ olarak alındı.

Post-Hoc güç analizi, GPower 3.0.1 (Universität Kiel, Almanya) yazılımı kullanılarak yapıldı (Faul, Erdfelder, Lang, ve ark., 2007). Buna göre çalışmanın en önemli ilişkisel sonucu olarak görülen; ağrı ve eklemde yanık varlığı değişkenleri ile Q-DASH puanları arasındaki etkileşimin çoklu doğrusal regresyon kullanılarak yapılan analizi sonucu elde edilen $R^{2}$ değeri (0.62) kullanılıp etki büyüklüğü 1,6315789 olarak hesaplandı. 1,6315789 etki büyüklüğünde, 0,05 yanılma yüzdesi kullanılarak, 34 birey için çalışmanın gücü \%99 olarak belirlendi.

\section{SONUÇLAR}

Çalışmaya üst ekstremite yanık yaralanması olan 34 (26 K; 8 E) birey dahil edildi. Çalışmaya dahil edilen bireylerin yanık lokalizasyon dağılımları incelendiğinde, bireylerin 20'si unilateral yanık yaralanmasına sahipken, 14'ü bilateral üst ekstremite yanık yaralanmasına sahiptir. Katılımcıların 15'inin yanık yaralanması eklemi içeriyorken, 19 bireyin yanık yaralanmasının eklemi içermediği tespit edildi. Bireylerin demografik, klinik değerlendirme parametreleri ve yanık yaralanmasına ilişkin detaylı özellikleri Tablo 1'de gösterilmiştir. Çok değişkenli doğrusal regresyon analiz sonuçlarına göre, Q-DASH anketi puanı için eklemi içeren yanık varlığı ve ağrı düzeyinin, istatistiksel olarak anlamlı belirleyici faktörler olduğu bulunmuştur (R2=0,620, p<0,05;Tablo 2).

Eklemde yanık yaralanması olan ve olmayan bireylerin klinik ölçümlerini karşılaştırdığımızda, eklemde yanık yaralanması olan bireylerin daha yüksek Q-DASH anketi puanına, kinezyofobi ve ağrı düzeyine sahip olduğu bulunurken, her iki elde de kavrama kuvvetinin daha düşük olduğu bulundu $(p<0,05$; Tablo 3). Bilateral ve unilateral üst ekstremite yanık yaralanması olan bireylerin Q-DASH anketi puanı, kinezyofobi, kavrama kuvveti ve ağrı parametrelerini karşılaştırdığımızda, gruplar arasında anlamlı bir fark saptanmadı ( $p>0,05$; Tablo 4).

Tablo 1. Grubun demografik/klinik değerlendirmeleri ve yanık yaralanmasına ilişkin özellikleri

\begin{tabular}{lc}
\hline \multicolumn{2}{c}{ Demografik Özellikler (n=34) } \\
\hline Yaş (yıl) & $30,52 \pm 10,50$ \\
\hline Boy (cm) & $166,47 \pm 9,95$ \\
\hline Vücut Ağırlığı (kg) & $68,32 \pm 12,87$ \\
\hline VKI (kg/m²) & $24,62 \pm 4,08$ \\
\hline Cinsiyet (K/E) & $26 / 8$ \\
\hline Unilateral/bilateral yanık varlığı & $20 / 14$ \\
\hline Eklemi içeren/içermeyen yanık varlığı & $15 / 19$ \\
\hline \multicolumn{2}{c}{ Klinik Değerlendirmeler } \\
\hline Q-DASH & $31,01 \pm 16,91$ \\
\hline Kavrama Kuvveti (Yanık taraf) (kg) & $21,44 \pm 7,41$ \\
\hline Kavrama Kuvveti (Sağlam/Daha az yanık taraf) (kg) & $24,49 \pm 6,54$ \\
\hline Kinezyofobi & $42,17 \pm 5,54$ \\
\hline Ağrı & $4,76 \pm 1,67$ \\
\hline $\begin{array}{l}\text { Q-DASH= Hızlı Kol-Omuz-El Sorunları Anketi; TYYA= toplam yanık yüzey } \\
\text { dif=distal interfalangeal; pif: proksimal interphalangeal }\end{array}$ & mkf=metakarpofalangeal;
\end{tabular}


Tablo 1. Grubun demografik/klinik değerlendirmeleri ve yanık yaralanmasına ilişkin özellikleri (Devamı)

\begin{tabular}{|c|c|c|}
\hline \multicolumn{3}{|c|}{ Yanık yaralanmasına ilişkin özellikler } \\
\hline TYYA (\%) & & $4,64 \pm 2,87$ \\
\hline \multirow{4}{*}{$\begin{array}{l}\text { Yanığın Oluşma } \\
\text { Şekli }\end{array}$} & Haşlanma & $27(\% 79,4)$ \\
\hline & Alev & $4(\% 11,8)$ \\
\hline & Temas & $2(\% 5,9)$ \\
\hline & Elektrik & $1(\% 2,9)$ \\
\hline \multirow[t]{2}{*}{ Yanık Derinliği } & 2. derece derin ve yüzeyel & $28(\% 82,4)$ \\
\hline & 2. derece derin ve 3 . derece & $6(\% 17,6)$ \\
\hline \multirow[t]{8}{*}{ Yanık Lokalizasyonu } & El dorsali ve el bileği & $10(\% 29,4)$ \\
\hline & El Dorsali & $7(\% 20,6)$ \\
\hline & Önkol & $7(\% 20,6)$ \\
\hline & El dorsal ve palmar yüzeyi & $4(\% 11,8)$ \\
\hline & El dorsal ve palmar yüzeyi+ el bileği & $2(\% 5,9)$ \\
\hline & El dorsali+ el bileği+ önkol & $2(\% 5,9)$ \\
\hline & Elin palmar yüzeyi & $1(\% 2,9)$ \\
\hline & Dirsek ve önkol & $1(\% 2,9)$ \\
\hline \multirow[t]{5}{*}{ Etkilenen Eklem } & El bileği, mkf ve pif eklemler & $3(\% 20)$ \\
\hline & El bileği ve mkf eklem & $7(\% 46,6)$ \\
\hline & mkf,dif ve pif eklemler & $2(\% 13,4)$ \\
\hline & El bileği eklemi & $2(\% 13,4)$ \\
\hline & Dirsek & $1(\% 6,6)$ \\
\hline
\end{tabular}

Q-DASH= Hızlı Kol-Omuz-El Sorunları Anketi; TYYA= toplam yanık yüzey alanı; mkf=metakarpofalangeal; dif=distal interfalangeal; pif: proksimal interfalangeal

Tablo 2. Üst ekstremite ile ilişkili özür düzeyini etkileyen faktörlerin çoklu doğrusal regresyon analiz sonuçları

\begin{tabular}{|c|c|c|c|c|c|c|}
\hline \multirow[t]{2}{*}{$(n=34)$} & \multirow{2}{*}{$\begin{array}{c}\text { Bağımsız } \\
\text { Değişkenler }\end{array}$} & \multirow{2}{*}{$\begin{array}{c}\text { Standartlaştırılmamış } \\
\text { Regresyon Katsayıları } \\
\text { (B) }\end{array}$} & \multicolumn{2}{|c|}{$\% 95$ GA } & \multirow[t]{2}{*}{ p } & \multirow[t]{2}{*}{$\mathbf{R}^{2}$} \\
\hline & & & Alt Sınır & Üst sınır & & \\
\hline \multirow[t]{2}{*}{ Q-DASH } & $\begin{array}{l}\text { Eklemde yanık } \\
\text { varlığı }\end{array}$ & 17,840 & 9,478 & 26,202 & $<0.001$ & \multirow[t]{2}{*}{0.620} \\
\hline & Ağrı & 4,006 & 1,497 & 6,514 & 0.003 & \\
\hline
\end{tabular}

Q-DASH= Hızlı Kol-Omuz-El Sorunları Anketi; GA=Güven aralığı, n= katılımcı sayısı

Tablo 3. Eklemi içeren veya içermeyen yanık yaralanması olan bireylerin Q-DASH puanı, kavrama kuvveti, kinezyofobi ve ağrı düzeylerinin karşılaştırılması

\begin{tabular}{|c|c|c|c|}
\hline $\begin{array}{l}\text { Fonksiyonel } \\
\text { değerlendirmeler }\end{array}$ & $\begin{array}{c}\begin{array}{c}\text { Eklemde yanık }(+) \\
(n=15)\end{array} \\
\text { Ort } \pm \text { SS }\end{array}$ & $\begin{array}{c}\begin{array}{c}\text { Eklemde yanık (-) } \\
(n=19)\end{array} \\
\text { Ort } \pm \text { SS }\end{array}$ & p \\
\hline Q-DASH & $44,54 \pm 11,48$ & $20,33 \pm 12,20$ & $<0,001^{*}$ \\
\hline $\begin{array}{l}\text { Kavrama Kuvveti } \\
\text { (Yanık taraf) }\end{array}$ & $17,28 \pm 4,27$ & $24,73 \pm 7,79$ & $0,001^{*}$ \\
\hline $\begin{array}{l}\text { Kavrama Kuvveti } \\
\text { (Sağlam/daha az yanık } \\
\text { taraf) }\end{array}$ & $21,86 \pm 4,35$ & $26,57 \pm 7,30$ & $0,027^{*}$ \\
\hline Kinezyofobi & $46,53 \pm 4,76$ & $38,73 \pm 7,65$ & $0,002^{*}$ \\
\hline Ağrı & $5,65 \pm 1,41$ & $4,06 \pm 1,56$ & $0,003^{*}$ \\
\hline
\end{tabular}


Tablo 4. Bilateral veya unilatrel üst ekstremite yanık yaralanması olan bireylerin Q-DASH puanı, kavrama kuvveti, kinezyofobi ve ağrı düzeylerinin karşılaştırılması

\begin{tabular}{|c|c|c|c|}
\hline \multirow[t]{2}{*}{ Fonksiyonel değerlendirmeler } & $\begin{array}{c}\text { Unilateral Yanık } \\
\text { Grubu } \\
(\mathrm{n}=20)\end{array}$ & $\begin{array}{l}\text { Bilateral Yanık Grubu } \\
(n=14)\end{array}$ & \multirow[t]{2}{*}{$\mathbf{p}$} \\
\hline & Ort \pm SS & Ort \pm SS & \\
\hline Q-DASH & $30,10 \pm 12,93$ & $32,30 \pm 21,87$ & 0,904 \\
\hline Kavrama Kuvveti (Yanık taraf) & $20,42 \pm 6,71$ & $22,90 \pm 8,35$ & 0,478 \\
\hline $\begin{array}{l}\text { Kavrama Kuvveti } \\
\text { (Sağlam/daha az yanık taraf) }\end{array}$ & $23,86 \pm 5,05$ & $25,40 \pm 8,34$ & 0.616 \\
\hline Kinezyofobi & $43,50 \pm 5,49$ & $40,28 \pm 9,69$ & 0,290 \\
\hline Ağrı & $4,52 \pm 1,21$ & $5,10 \pm 2,18$ & 0,522 \\
\hline
\end{tabular}

\section{TARTIŞMA}

$\mathrm{Bu}$ çalışmada üst ekstremite yanık yaralanması olan bireylerde özellikle eldeki eklemlerden birini içeren yanık varlığının ve ağrı düzeyinin erken dönemde üst ekstremite ile ilişkili özür düzeyi (QDASH anketi) açısından temel belirleyiciler olduğu gösterildi. Ayrıca eklem bölgesini içeren yanık yaralanması olan bireylerin, özür düzeyindeki olumsuz etkilenime ek olarak eklemi içeren yanık yaralanması olmayan bireylere göre her iki elin kavrama kuvvetinin daha az olduğu, kinezyofobi ve ağrı düzeyinin ise daha yüksek olduğu belirlendi.

Yaralanma sonrasında erken dönemde ortaya çıkan ağrı yanık sonrası iyileşme sürecinde bireyin fonksiyonelliği ile birlikte yaşam kalitesini ve günlük yaşam aktivitelerini etkileyen en önemli faktörlerden birisidir (Ghezeljeh ve ark., 2017). Ağrının ve kinezyofobinin hem üst hem de alt ekstremite yanıklarında fonksiyonellik üzerindeki olumsuz etkisi göz önünde bulundurulduğunda, erken dönemde ağrı yönetiminin sağlanması tedavinin başarısı için bir önkoşuldur (Özkal ve ark., 2017; Schneider ve ark., 2012). Çalışmamızın sonuçları ile uyumlu olarak, Leblebici ve arkadaşları (Leblebici, Adam, Bagis ve ark., 2006) eklem kontraktürlerinin kronik dönem yanık yaralanması olan bireylerin fiziksel fonksiyonlarını, ağrısını ve yaşamsal faaliyetlerini etkilediğini göstermiştir. Artmış ağrı düzeyinin, eklem hareket açıklığını ve eklem mobilitesini limitleyerek etkilenen ekstremitenin fonksiyonunu olumsuz yönde etkilediği bilinmektedir (Schneider ve ark., 2012). Bilateral ve unilatarel üst ekstremite yanık yaralanması olan bireylerin sonuçlarını karşılaştırdığımızda, üst ekstremite ile ilişkili özür düzeyi, kavrama kuvveti, kinezyofobi ve ağrı düzeyinin benzer olduğu belirlendi. Ağrı düzeyinin üst ekstremite fonksiyonunun belirleyicilerden birisi olduğunu gösterdiğimiz çalışmamızda, bilateral ve unilateral yanıklarda bireylerin ağrı düzeylerinin benzer olması grupların özür düzeyinin de benzer olmasına yol açmış olabileceği görüşündeyiz.

Eli içeren yanıklarda yaralanma sonrası üst ekstremite fonksiyonel durumun nasıl değerlendirilmesi gerektiğine ilişkin bir fikir birliği bulunmasa da, hasta tarafından cevaplandırılan anketlerin yaşam kalitesi ile yüksek düzeyde körele olması sebebiyle kullanımı akut dönemden itibaren önerilmektedir (Johnson ve Chung, 2017). Üst ekstremite yanıklarında eklem hareket açıklığındaki kayıplar sıklıkla görülmesine karşın, ölçümlerin standardize edilememesi ve çalışmalarda eklem hareket açıklığı ölçümü ile fonksiyonel performans gelişiminin zayıf bir ilişkide olması sebebiyle özellikle pansumanın devam ettiği erken dönemde değerlendirilmesi önerilmemektedir (Kowalske, 2009). Clifford ve arkadaşları (Clifford, Hamer, Phillips ve ark., 2013) eli içeren üst ekstremite yanıklarında, kavrama kuvvetinin yanık yaralanmasını takiben erken dönemden itibaren güvenli bir şekilde uygulanabileceği göstermiştir. Ancak, kavrama kuvvetindeki kayıplar klinisyenlere el fonksiyonları ile ilgili bir fikir verse de gülük yaşam aktiviteleri ve fonksiyonların hangi komponentlerinde kayba yol açtığını yorumlama güçlüğü ölçümün en önemli limitasyonudur (Clifford ve ark., 2013). Bu sebeple kavrama kuvveti ölçümünün hasta tarafından cevaplandırılan anketlere ek olarak yapılması önerilmektedir (Johnson ve Chung, 2017).

Literatürdeki rehberlerin önerdiği değerlendirme yöntemleri ile benzer ölçümlerinin yapıldığı çok az sayıda çalışma bulunmaktadır (Umraw, Chan, Gomez ve ark., 2004; Mazzetto-Betti ve ark., 2009). Bu çalışmaları incelediğimizde eli içeren üst ekstremite yanığı olan bireylerde kronik dönemde (Umraw ve ark., 2004) el fonksiyonları Michigan el sonuç anketi ile değerlendirilmiş ve fonksiyonların ağrı ilişkili olduğu 
belirlenmiştir. Kronik dönemde yüksek voltaj elektrik yanıklarında üst ekstremite ile ilişkili özür düzeyininin Kol, Omuz ve El Sorunları AnketiDASH- ile değerlendirildiği bir başka çalışmada ve el/parmak kavrama kuvvetinin DASH anketi puanı için bir belirleyici olduğunu gösterilmiştir (Mazzetto-Betti ve ark., 2009). Ayrıca, elektrik yanık yaralanması olan bireylerin kavrama kuvveti normale yakın ise, günlük yaşam aktivitelerini bağımsız ve düzenli olarak gerçekleştirebildiklerini belirtmişlerdir (Mazzetto-Betti ve ark., 2009). Literatürde akut dönemde yapılan benzer bir çalışma olmamasına karışın, çalışmamızda kronik dönemde yapılmış çalışmaların sonuçları ile uyumlu olarak yaralanmanın olduğu bölgede özellikle eklemi içeren yanıklarda artmış ağrı düzeyinin eklem hareket açıklığı ve mobilitesindeki yol açtığı olası kayıpların özür düzeyini olumsuz yönde etkilemiş olabileceğini düşünmekteyiz.

Yanık hastalarının iyileşme sürecinin takip edildiği bir çalışmada (Jarrett ve ark., 2008) bireylerin hastaneden taburculukta, taburculuk sonrası 1. ve 3. ayda üst ekstremite ile ilişkili özür düzeyinin hastaneye kabuldeki durumuna göre daha kötü olduğu gösterilmiştir. Hastaneye kabulde bireylerin fonksiyonlarının daha iyi olmasının henüz etkilenen eklemlerde kontraktür oluşmamış olması ile ilişkili olabileceği düşünülürken, ilerleyen dönemlerde geçirilen cerrahi operasyonların yanık yaralaması olan bireylerin fonksiyonelliğini olumsuz etkilediği belirtilmiştir. Ayrıca, TYYA ile üst ekstremite fonksiyonlarının ilişkili olduğu ve bireylerin üst ekstremite fonksiyonlarının normal değerlerine yaklaşık 6. ayda yaklaştığı belirtilmiştir. Literatür TYYA ve yaşam kalitesinin ilişkili olduğu konusunda hem fikir olsa da, TYYA ve fonksiyonellikle ilişkisini araştıran çalışmaların sonuçları çelişkilidir (Jarrett ve ark., 2008; Özkal ve ark., 2017; Leblebici ve ark., 2006). Bu çalışmada da TYYA ve üst ekstremite ile ilişkili özür düzeyi arasında anlamlı bir ilişki olduğu bulunsa da, TYYA'nın Q-DASH anketi puanının temel belirleyicisi olmadığı görüldü. $B u$ durum çalışmaya dahil edilen bireylerin TYYA'nın birbirleri ile yakın olmasının ve dar bir aralıkta (\%112) seyretmesinin bu sonuca yol açmış olabileceği görüşündeyiz.

Çalışmada bireyler yaralanma sonrasında ilk bir hafta içerisinde değerlendirilmiş olmasına karşın, bireylerin yaralanma sonrasında 1. gün ve 7. gün ağrısının farklı seyredebileceğini düşünmekteyiz. Bütün bireylerin yaralanma sonrası aynı günde değerlendirilmemiş olması çalışmanın en önemli limitasyonudur. Çalışmanın diğer limitasyonu dahil edilen bireylerin yanık lokalizyonundaki heterojen dağılımdır. Regresyon analizi ile lokalizasyonun etkisine bakılmış olsa da, gelecekteki çalışmalar daha homojen gruplarda (elin dorsal yanıkları, el bileği yanıkları vb.) yaralanmanın farklı dönemlerinde uzun süreli takip çalışmaları ile özür düzeyini etkileyen klinik faktörleri araştırmalıdır.

$\mathrm{Bu}$ çalışmanın sonucunda, akut dönemde üst ekstremite yanık yaralanması olan bireylerde eklemi içeren yanığın ve artmış ağrının özür düzeyi üzerine etkisi vurgulanmış oldu. Akut dönemde bireye özel rehabilitasyon programı oluşturulurken, üst ekstremitede herhangi bir eklemi içine alan yanıklarda, eklemi içermeyen yanıklara göre hem özür seviyesinin hem de ağrı ve kinezyofobi düzeyinin erken dönemde daha çok etkilendiği mutlaka göz önünde bulundurulmalıdır. Artmış ağrı ve kinezyofobi düzeyinin kronik dönemde ortaya çıkarabileceği komplikasyonların engellenmesi için erken dönemde ağrı kontrolünün sağlanması ile ilgili tedavi seçeneklerinin programa dahil edilmesi önemlidir. Bilateral ve unilatarel yanığı olan bireylerin klinik sonuçları benzer olmasına rağmen, yüksek ağrı düzeyinin özür düzeyinde kötüleşmeye neden olabileceği mutlaka dikkate alınmalıdır. Bu bağlamda, ağrının ve yanık lokalizasyonun etkisinin gösterildiği bu çalışma sonuçları ile kronik dönemde ortaya çıkabilecek fonksiyonel kayıpları önleyebilecek, bireye özel rehabilitasyon programının oluşturulmasında alanda çalışan klinisyenlere yol gösteri olacağı görüşündeyiz.

\section{Araştırmacıların Katkı Oranı}

Fikir/Kavram: ÖÖ, Çalışmanın tasarımı: ÖÖ,ST; Süpervizyon: ST; Veri toplama ve/veya işleme: ÖÖ; Analiz ve/veya Yorumlama: ÖÖ, ST; Literatür Tarama: ÖÖ, ST; Makale Yazımı-ÖÖ; Eleştirel İnceleme: ÖÖ,ST.

\section{Çıkar Çatışması Beyanı}

Yazarlar arasında çıkar çatışması bulunmamaktadır.

\section{Destek/Teşekkür}

Çalışma sırasında hiçbir kurum ya da kişiden finansal destek alınmamıştır.

\section{Kaynaklar}

Arifi, H. M., Duci S. B., Zatriqi V. K., Ahmeti H. R., Haxhiu I. I., Mekaj A.Y., et al. (2014). A retrospective study of 572 patients with hand burns treated at the Department of Plastic Surgery Kosovo during the period 2000-2010. Int J Burns Trauma, 4(1), 7-13.

Bellace, J. V., Healy, D., Besser, M. P., Byron, T., \& Hohman, L. (2000). Validity of the Dexter Evaluation System's Jamar 
dynamometer attachment for assessment of hand grip strength in a normal population. J Hand Ther, 13(1), 46-51.

Bijur, P.E., Silver, W., \& Gallagher, E.J. (2001). Reliability of the Visual Analog Scale for measurement of acute pain. Acad Emerg Med, 8(12), 1153-7.

Clifford, M.S., Hamer, P., Phillips, M., Wood, F.M., \& Edgar, D.W. (2013). Grip strength dynamometry: Reliability and validity for adults with upper limb burns. Burns, 39(7), 1430-6.

Düger, T., Yakut, E., Öksüz, C., Yorukan, S., Bilgutay, B., Ayhan, Ç., et al. (2006). Reliability and validity of the Turkish version of the Disabilities of the Arm, Shoulder and Hand (DASH) Questionnaire. Fizyoter Rehabil, 17(3), 99-107.

Edlich, R.F. Larkham, N. O'Hanlan J T., Berry, R., Hiebert, J., Rodeheaver, G.T., et al. (1978). Modification of the American Burn Association injury severity grading system. JACEP, 7(6), 226-8.

Faul F., Erdfelder E., Lang A.G., \& Buchner A. (2007). G* Power 3: A flexible statistical power analysis program for the social, behavioral, and biomedical sciences. Behav Res Methods, 39(2), 175-191.

Ghezeljeh, T.N., Ardebili, F.M., \& Rafii, F. (2017). The effects of massage and music on pain, anxiety and relaxation in burn patients: Randomized controlled clinical trial. Burns, 43(5), 1034-1043.

Jarrett, M., McMahon, M., \& Stiller, K. (2008). Physical outcomes of patients with burn injuries-a 12 month follow-up. J Burn Care Res, 29(6), 975-84.

Johnson, S.P, \& Chung, K.C. (2017). Outcomes assessment after hand burns. Hand Clin, 33(2), 389397.

Johnson, R. M, \& Richard, R. (2003). Partial-thickness burns: identification and management. Adv Skin Wound Care, 16(4), 178-87.

Knight, A., Wasiak, J., Salway, J., \& O'Brien, L. (2017). Factors predicting health status and recovery of hand function after hand burns in the second year after hospital discharge. Burns, 43(1), 100-106.

Kowalske, K. (2009). Outcome assessment after hand burns. Hand Clin, 25(4), 557-561.

Leblebici, B., Adam, M., Bagis, S., Tarim, A.M., Noyan, T., Akman, M.N., et al. (2006). Quality of life after burn injury: the impact of joint contracture. J Burn Care Res, 27(6), 864-8.

Luce, E.A. (2000). The acute and subacute management of the burned hand. Clin Plast Sur, 27(1), 49-63.

Mazzetto-Betti, K.C., Amâncio, A.C., Farina, J.A.Jr., Barros, M.E., \& Fonseca, M.C. (2009). High-voltage electrical burn injuries: functional upper extremity assessment. Burns, 35(5), 707-13.

Omar, M.T., Hegazy, F.A., \& Mokashi, S.P. (2012). Influences of purposeful activity versus rote exercise on improving pain and hand function in pediatric burn. Burns, 38(2), 261-8.

Özkal, Ö., Topuz, S., Konan, A., \& Kısmet, K. (2017). Alt ekstremite yanık yaralanması olan bireylerde ağrı, kinezyofobi, denge ve fonksiyonellik arasındaki ilişkinin incelenmesi. Ankara Eğitim ve Araştırma Hastanesi Tıp Dergisi, 50(3), 122-128.

Schneider, J.C., Holavanahalli, R., Helm, P., O'Neil, C., Goldstein, R., \& Kowalske, K. (2008). Contractures in burn injury. Part II. Investigating joints of the hand. $J$ Burn Care Res, 29(4), 606-13.

Schneider, J.C., Qu, H.D., Lowry, J., Walker, J., Vitale, E., \& Zona M. (2012). Efficacy of inpatient burn rehabilitation: a prospective pilot study examining range of motion, hand function and balance. Burns,38(2), 164-71.

Sgroi, M.I., Willebrand, M., Ekselius, L., Gersin, B., \& Andersson G. (2005). Fear-avoidance in Recovered Burn Patients: Association with Psychological and Somatic Symptoms. J Health Psychol, 10(4), 491-502.

Umraw, N., Chan, Y., Gomez, M., Cartotto, R.C., \& Fish,
J.S. (2004). Effective hand function assessment after burn injuries.J Burn Care Rehabil, 25(1), 134-9.

Wang K.A., Sun Y., Wu G.S., Wang Y.R., \& Xia Z.F. (2015).

Epidemiology and outcomes analysis of hand burns: A 5year retrospective review of 378 cases in a burn center in Eastern China. Burns,41(7), 1550-5.

Wu, A., Edgar, D.W., \& Wood, F.M. (2007). The QuickDASH is an appropriate tool for measuring the quality of recovery after upper limb burn injury. Burns, 33(7), 843-9.

Yılmaz, O.T., Yakut Y., Uygur F., \& Ulug N. (2011). Tampa Kinezyofobi Ölçeği'nin Türkçe versiyonu ve test-tekrar test güvenirliği. Fizyoter Rehabil, 22(1), 44-49. 